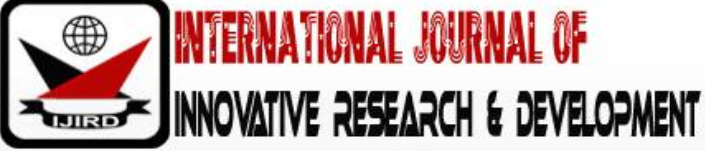

ISSN 2278 - 0211 (Online)

\section{Impact of Human Resource Management on Employees' Sustainability Development in Ado-Ekiti, Nigeria}

\author{
Aw oyemi Samuel Olausi \\ Lecturer, Department of Business Administration, Federal Polytechnic, Nigeria \\ Akinfolarin Modupe Odunayo \\ Instructor, Department of Banking and Finance, Federal Polytechnic, Nigeria
}

\begin{abstract}
:
This study examines the impact of human resource management on banks employees' sustainability development in AdoEkiti. This study adopts the survey design. The population comprises all human resources in commercial banks operating Ado-Ekiti. The branch managers and senior officers of the 16 banks were selected using convenient sampling; a nonprobabilistic sampling technique were selection of subjects are conveniently accessible and their proximity to the researcher with 3 respondents from each bank. All the responses are collected on five point Likert scale using a close-ended questionnaire. Regression analysis is applied to test the relationship between HRM variables and banks employee's sustainability development using SPSS Version 16. The results indicate that there is a positive and significant relationship between human resource management and banks employees' sustainability development. Based on these, it therefore concludes that effective human resource management is indispensible to employees' sustainable development. However, it is study recommended that all banks should adopt and implement the best human resource management practices (human resource planning, job analysis, recruitment, selection, compensation performance appraisal and training) for better employees' sustainable development.
\end{abstract}

Keywords: Human resource management, sustainable development, banks employees

\section{Introduction}

In the present day's cutting-edge aggressive business condition, firms are confronting rising difficulties through picking up and streamlining human asset. Human capital is one of the key resources in setting up a managed upper hand (Barney, 1991). In the offer to beat the difficulties, there has for the most part been the requirement for an expansive Human Resources Management (HRM) practices to make an interpretation of organization's human resources into a sustainable upper hand. The accomplishment of most, if not all, organizations depends to a great extent is the requirement for a way to deal with accomplish better performance, to begin and execute HRM practices. This acknowledgment fortifies the basic job HRM practices play in this all around current and progressively focused business landscape.

Administrators and other authoritative pioneers confronted the issues of resources; how to locate a gifted individual for the correct errands, how to ensure individuals do what they ought to do, how to prop individuals up when the time is intense (Senyucel, 2009). These and numerous others have been the test looked by organizations whether open, private or philanthropic.

Supervisors and hierarchical pioneers are in charge of landing the position as well as finding the perfect individuals for the correct job, taking care of business on the opportune time, spare expense liaises with the partners, create and hold existing employees, keep employees confidence high and increment worker's performance. (Senyucel. 2009)

Notwithstanding the significance joined to human resource management as drive power to hierarchical achievement, there is a minimal observational examination to discover the effect of human resource management on employees' sustainable development particularly in Nigerian banks, thus, required this investigation. Scholarly enthusiasm for Human Resource Management is additionally confirming by the level of consideration it has gotten in the course of the most recent couple of decades (Senyucel, 2009). The relationship between Human Resource Management and employees' sustainable development has been the subject of concern and enthusiasm to numerous analysts and researchers.

Human Resources Management practices is a type of framework in which an arrangement of particular yet interrelated exercises, capacities and procedures are coordinated at pulling in, creating, and keeping up or arranging association's human resources so far as that is concerned employees (Lado and Wilson, 1994). HRM allude to hierarchical exercises coordinated at dealing with the pool of human asset and guaranteeing that the resources are utilized towards the satisfaction of authoritative objectives (Schuler and Jackson, 1987)

Throughout the years in Nigeria, firms' performances particularly banks, has been blocked by low performance and here and now crumple, falls in the venture (Meggision, 1992). Numerous financial specialists have looked for an 
answer to this terrible circumstance. In this manner, firms have connected on a few hierarchical surveys and x-rayed the issue and the route forward. Existing Literature have incredibly evoked the colossal commitments of Human Resources Management hones on organizations' performance (Agyapomaa, 2011). The performances of organizations are an impression of employees' development. All the more particularly, HRM is guessed to satisfy employees' needs which improves great demeanours, and in this manner prompts the employees' development and performance (Edger and Geare, 2005).

Regardless, in the journey to accomplish practical upper hands in this tempestuous business condition, organizations need to enhance their Human resources to be a contender. Such change requires an estimation of the individual centrality of the HRM hones as far as their effects on employees' development. Despite the fact that reviews have been led on Commercial banks human asset management rehearses at the level of the head office (Owusu, Antwi, Ampadu and Osei-Boateng, 2016), this investigation at that point centers around the examination of the human asset management hones and the effect on employees' development at the branch levels in the would like to inspect how HRM hones were been led and its relationship with employees' sustainability development.

The main objective of the study is to examine the impact of human resource management on banks employees' sustainability development in Ado-Ekiti, Nigeria, while the specific objectives are: to analyze conceptually how human resource management practices affects banks employees' sustainable development in Ado-Ekiti, Nigeria; and to examine empirically the relationship between human resource management and bank employees' sustainability development in Ado-Ekiti, Nigeria. In consonance with the research objectives, the following research questions were answered: Does human resource management practice affect bank employees' sustainability development? Is there any significant relationship between human resource management and banks employees' sustainability development? Accordingly, the following research hypotheses were tested: $\mathrm{Ho}_{1}$ :Human resource management practice does not affect bank employees' sustainability development. $\mathrm{Ho}_{2}$ : There is no significant relationship between human resource management and banks employees' sustainability development.

\subsection{Conceptual Review}

Human resource management is a multidisciplinary authoritative capacity that draws speculations and thoughts from different fields, for example, management, psychology, social science and financial aspects (Storey, 1992). Human resource management went for creating individuals through work (Bratton and Gold, 2001). Human resource management incorporates managerial exercises that are related to planning, recruitment, selection, orientation, training, appraisal, inspiration and compensation (Story, 1992). Robbins and Judge (2009) total up human resource management by five key ideas: rousing, restraining, overseeing strife, staffing and training.

Human resource management is a comprehensively endorsed idea with the point of dealing with the employees' of an organization and is identified with workforce fascination, selection, training, appraisal, and fulfilling (Robbins and Judge, 2009).

The impact of chiefs' conduct on the employees' performance is examined by McGregor (1960) in his proposed 'Theory X - and Theory $Y^{\prime}$. Hendry (1995) states that now and again, tolerating the standards of human resource management is simply an acknowledgement of human resources as the most basic resources of the organization. In any case, in some different cases, it stresses relating the elements of the employees to the organization's procedure. In Janger (1977) perspective, HRM might be just mirroring the human resources' significance to an organization.

Armstrong (2003) trusts that human resources are the most prized resources of any organization who add to the organization's accomplishments. He likewise characterized human resource management as the key methodology toward dealing with the employees'.

Ordinarily, human resources were for the most part considered as a cost which must be controlled and limited. In any case, it is currently understood that they can considerably add to the organization's monetary performance.

Sustainability has been subjecting of thought and appearance in the field of management for quite a while. Recently, anyway that the connection among sustainability and HRM issues, appear to have gotten consideration, where practical human resource management has created distinctive methodologies, in recognizing the advantage of the discernment, against the customary HRM, which is a drive towards a feasible development (Ehnert, 2006). Sustainability is a developing methodology that advances the utilization of human, regular and monetary resources to enhance the economy, the earth, and society in an incorporated path to support present and future age. The idea is a worldwide strategy topic, generally, use since 1987 when the United Nation World Commission on Environment and Development characterizes reasonable development as "development that addresses the issue of the present without trading off the capacity of future age to address their very own issues".

Human resource management (HRM) alludes to the strategies and practices engaged with doing the human asset parts of a management position including human asset planning, job analysis, recruitment, selection, orientation, compensation, performance appraisal, training and development and work connection (Aguinis, 2009). HRM is made out of the approaches, practices and frameworks that impact employees' conduct, state of mind and performance (Altarawmneh and Al-Kilani 2010). The assumed connection between individual performance and hierarchical performance has been entrenched in business writing (Appelbaum, Bailey, Berg and Kalleberg, 2000). Mindful of such a reality, organizations have been in a condition of consistent look for influences of worker performance. The influences are the components that advance or improve the level of representative exertion and exercises identified with his/ her work. The scan for the influences or factors that upgrade worker performance has dependably been a major worry for industrialists and scientists. Taylor's medicines which searched for the 'one most ideal route' of creation connected to a 
reward bundle which empowered financial man to boost salary was an early endeavour to couple worker inspiration with profitability and output (Arogyaswamy and Byles, 1987).

Aguinis (2009) regard HRM as "involving all management decision that influences the relationship between the organization and employees, its human resources (Arthur 1992). HRM practices, in any organizations, are a moderator among the technique and approaches of HRM and HRM result. HRM include job analysis, orientation, performance appraisal, human resources planning, work relations, selection, recruitment, compensation and training development (Bailey, 1993). HR practices and job satisfaction are studied widely in different parts of the world. It is assumed that HR practices are nearly associated with job satisfaction (Bartel 1994). Since many researchers' practitioners trust that sound HR practices result in a better level of job satisfaction which at last enhances organizational performance (Becker and Gerhart 1996). A few researchers centreon the general job satisfaction of employees' (Becker and Huselid, 1999) while some satisfaction with pay, promotion, manager, or colleagues.

\subsubsection{Selection}

The HR work framework includes a tight division of work and narrowly designed and specialized jobs. In such a framework, limited worker participation exists and personnel strategy determines detailed standards concerning profession progression and compensation (Harel and Tzafrir, 1999). One of the clearest expositions of this topic was given by Schuler and Jackson (1987). The model was based on the generic aggressive systems outlined by Porter (1980), that is, quality enhancement, innovation and cost leadership or reduction. For every procedure, Schuler and Jackson (1987) develop an arrangement of 'needed job practices' which fluctuate over a number of dimensions and then recommended an arrangement of human asset rehearses that are needed to bring about these practices.

\subsubsection{Training}

According to Harel and Tzafrir (1999), training can influence performance by improving aptitudes and capacities relevant to employees' errands and development (Gerhart, 1990). Burke and Day, (1986) indicate that training emphatically influences the level of performance of managers (Hamel and Prahalad, 1994). So also, Bartel (1994) finds that investment in training helps worker spirit and increases performance. In general, training enables employees' to get more noteworthy competencies that are needed to play out their jobs efficiently and successfully (Harel and Tzafrir, 1999).

\subsubsection{Performance Appraisal}

Employees develop more inspirational attitudes when they get great results. For instance, the level of extrinsic rewards (amount of pay) employees' get has been found to be negatively related to turnover level (Harel and Tzafrir, 1999) The level of social rewards individuals get has likewise been found to emphatically influence job attitudes (Harel and Tzafrir, 1999). For instance, the level of social help individuals get from colleagues has been shown to decidedly influence their job satisfaction (Jones and Schaubreock, 2004). Management's endeavour to implement an exemplary control framework for reducing work costs by unilaterally increasing performance standards and maintaining wages and benefits is probably going to be met by strong resistance from a unionized work constraint. Resistances in the type of strikes, high grievance rates and adversarial work relations have been found to be greatly exorbitant to firms in term of productivity and quality.

\subsubsection{Worker Participation}

HR professionals must spotlight on continuous innovation by responding decidedly to new ideas and constantly keeping track of new trends. Innovative HR interventions, designed to ensure that individuals respond spontaneously to the basic demand of the organizations, can possibly build a sound and fruitful organization (Noe, Hollenbeck, Gerhart and Wright, 2007). Today, the organizations that essentially pursue the traditional ways to deal with managing individuals, obsessed with the setup HR framework that they have, seem, by all accounts, to be destined to perform at a mediocre level or more terrible (Lengnick-Hall C. and Kengnick-Hall M. 1988).

Organizational help is defined as "the extent to which employees perceived that the organization valued their contribution and cared about their prosperity" (Eisenberger, Huntington and Sava, 1986). The help that is provided by the organization is directly related to employees' performance. Employees exchange their genuine exertion for more noteworthy consideration, concern and bolster they received from their organization (Eisenberger, Huntington and Sava, 1986).

\subsubsection{Vocational Planning}

Some studies have revealed that developing a sense of equity on employees can increase satisfactory, commitment, exertion and performance (Folger and Cropanzano, 1998). According to Chatterjee and Pearson (2000), HR practitioners currently uphold hones that are in keeping with individual want and in addition the organizations' requirement (Chatterjee and Pearson, 2000).

The rationale that the human asset arrangements and practices of the firm have implication for the creation of upper hand by providing the organization with a unique wellspring of talent that is difficult to reproduce has been prevalent for a long time (Chatterjee and Pearson, 2000). This view has been recognized and followed up by academics and practitioners. For instance, Bailey (1993) contends that human talent is often 'under-utilized' and that organizational exertion from employees are probably going to provide a wellspring of upper hand that cannot be effortlessly replicated by contenders (Bailey, 1993) Internal work showcases that provide an opportunity for employees to advance within a firm 
and group-based production frameworks (Locke, 1976) are for the most part types of work organizations that have been argued to emphatically influence firm performance. In addition, it has been argued that the provision of job security encourages employees to work harder (Locke, 1976).

\subsubsection{Compensation}

Industrialists and researchers have been in constant look for variables that influence representative development (Chatterjee and Pearson, 2000). In his initial endeavour, Taylor (1911) has suggested prescriptions which looked for the 'one most ideal route' of development attached to a reward bundle which enabled 'economic man' to amplify income in return for his extraordinary exertion. This was an early endeavour to couple representative motivation with development (Porter, 1980)

\subsection{Human Resource Management and Employees' Sustainability Development}

The relationship between human resource practices and employees' development is an increasingly researched subject in human resource management (Edger and Geare, 2005; Farid and Khayal, 2015). All the more particularly, Human Resource Management is supposed to follow employees' needs which enhances great attitudes and subsequently leads to development (Edgar and Geare, 2005). This is in synch with social exchange hypothesis (SET) which contends that HRM rehearses provides positive and relevant exchange relationships among employees and boss - particularly when the needs of individual specialists are considered - to which employees respond with great attitudes and conduct (GouldWilliams and Davies, 2005).

Visitor (2002) has demonstrated that the effect of HRM on employees' and organizational development depend upon responses of specialists towards HRM rehearses. Along these lines, the effect of HRM hones move in the direction of the perception of employees. Qureshi, Tahir, Syed, and Mohammad. (2007) concluded that HRM hones are emphatically correlated with employees' development and performance.

\section{Methodology}

\subsection{Research Design}

The reason for our research is to examine the relationship between human resource management and employees' sustainability development. The population involves the entire workforce of the 16 business banks operating in Ado-Ekiti city. The branch managers and senior officers of the banks were selected using convenient sampling; a non-probabilistic sampling technique where a selection of subjects are conveniently open and their closeness to the analyst with 3 respondents from each bank. Essential data were used for the analysis. Responses are gathered from the 16 banks operating in Ado Ekiti city. The branch Managers and senior officers provided the information regarding human asset management in their banks. Data were collected through the administration of the structured questionnaire. The questionnaire consists of 30 close-ended questions. The questions measure the employees' selection, training, performance appraisal, vocational planning, worker participation, compensation and employees' sustainable development. Five point-Likert scale approach was adapted to rate response by respondents. The responses were rated as Strongly Agree (SA), (Agree), Neutral (N), Disagree (D), and Strongly Disagree (SD). The dependability of the examination instrument was tested using Cronbach's alpha. Descriptive measurement generated by SPSS version 16 was utilized. The factual analysis included regression analysis which was used to determine the relationship between human resource management (independent variables) and employees' sustainability development (dependent variable). The findings were presented in tabular formats.

\subsubsection{Reliability Test}

\subsubsection{Case Processing Summary}

\begin{tabular}{|c|c|c|}
\hline & $\mathbf{N}$ & $\mathbf{\%}$ \\
\hline Cases Valid & 48 & 100.0 \\
Excluded $_{\alpha}$ & 0 & .0 \\
Total & 48 & 100.0 \\
\hline
\end{tabular}

Table 1: Reliability Statistics for HRM Subscale

a. Listwise Deletion Based on All Variables in the Procedure

\subsubsection{Reliability Statistics}

\begin{tabular}{|c|c|}
\hline Cronbach's Alpha & Nof Items \\
\hline .735 & 16 \\
\hline
\end{tabular}

Table 2: Show the Cronbach's Alpha Value to Be

0.735 For the HRM Subscale, the Value Depicts a Reasonably Reliable Subscale 


\subsubsection{Case Processing Summary}

\begin{tabular}{|c|c|c|}
\hline & $\mathbf{N}$ & $\mathbf{\%}$ \\
\hline Cases Valid & 48 & 100.0 \\
Excluded $_{\alpha}$ & 0 & .0 \\
Total & 48 & 100.0 \\
\hline
\end{tabular}

Table 3: Reliability Statistics for Employees' Sustainable Development Subscale

a. Listwise Deletion Based on All Variables in the Procedure

\subsubsection{Reliability Statistics}

\begin{tabular}{|c|c|}
\hline $\begin{array}{c}\text { Cronbach's } \\
\text { Alpha }\end{array}$ & N of Items \\
\hline .869 & 14 \\
\hline
\end{tabular}

Table 4

From Table 4, the Cronbach's alpha value of 0.869 is indicative of a reliable subscale assessing employees' sustainable development.

In summary, the Cronbach's alpha test has shown the 30 questions in the questionnaire are reliable and internally consistent, while each subscale is also reliable and internally consistent.

\section{Summary of Qualitative Findings}

The following is a summary of the findings from the qualitative aspect of the research.

\begin{tabular}{|c|c|c|}
\hline S/ N & Question & Responses of Respondents \\
\hline 1 & $\begin{array}{c}\text { Does selection emphatically influence } \\
\text { employees' sustainability development? }\end{array}$ & $\begin{array}{c}\text { Selection is decidedly related to employees' } \\
\text { sustainability development especially when the } \\
\text { selection was done within the due procedure and } \\
\text { principle of selection. }\end{array}$ \\
\hline 2 & $\begin{array}{c}\text { Does training sway employees' sustainability } \\
\text { development? }\end{array}$ & $\begin{array}{c}\text { Employees' perform successfully and efficiently } \\
\text { through training opportunity given to them by the } \\
\text { human resource management department. }\end{array}$ \\
\hline 3 & $\begin{array}{c}\text { Can you say that, performance appraisal is } \\
\text { decidedly related to employees' sustainability } \\
\text { development? }\end{array}$ & $\begin{array}{c}\text { Appraisal practice is a pointer on the capacity on the } \\
\text { job until now performed. It also points out where } \\
\text { employees' need to improve upon. That shows that it } \\
\text { relates to employee's sustainable development. }\end{array}$ \\
\hline 5 & $\begin{array}{c}\text { Is profession planning emphatically related to } \\
\text { employees' development? }\end{array}$ & $\begin{array}{c}\text { Every employee aimed at developing a vocation by } \\
\text { putting up their best in order to be promoted. }\end{array}$ \\
\hline 5 & $\begin{array}{c}\text { Is compensation decidedly related to } \\
\text { employees' sustainability development? }\end{array}$ & $\begin{array}{c}\text { Compensation is term as security to employees' } \\
\text { when an organization has compensation bundle. It } \\
\text { encourage the development of its employees, hence, } \\
\text { we can say that compensation relates with } \\
\text { employees development. }\end{array}$ \\
\hline 6 & $\begin{array}{c}\text { Is employee participation decidedly related to } \\
\text { employee's sustainability development? }\end{array}$ & $\begin{array}{c}\text { Employee's participation increases self-assurance } \\
\text { and job satisfaction, it relates with employees' } \\
\text { sustainability development. }\end{array}$ \\
\hline
\end{tabular}

Table 5: Summarized Responses of Interviewees

In the subjective analysis conducted through semi-structured interviews, every one of the bank's managers and senior officers responded to the six questions and their different responses demonstrate that human resource management has significant and positive effects on employees' sustainability development.

\subsection{Test of Hypothesis}

- $\mathrm{H}_{02}$ : There is no significant relationship between human resource management and employees' sustainability development. 


\begin{tabular}{|c|c|c|c|c|c|c|}
\hline Group & $\begin{array}{c}\text { Number of } \\
\text { Respondents }\end{array}$ & $\begin{array}{c}\text { Computed } \\
\text { mean (x) }\end{array}$ & Computed r & p-value & $\begin{array}{c}\text { Critical } \\
\text { value }\end{array}$ & Decision \\
\cline { 1 - 3 } & 48 & 3.41 & & & Nil & $\mathrm{H}_{0}$ is rejected \\
Management & 48 & 3.17 & 0.765 & 0.000 & Employees' \\
$\begin{array}{c}\text { Eustainability } \\
\text { Development }\end{array}$ & & & & & \\
\hline
\end{tabular}

Table 6: The Relationship between Human Resource Management and Employees' Sustainability Development

Table 6 shows that the computed value of $r$ is 0.765 , and the $p$-value is 0.000 , which shows a significant result. This leads to the rejection of the $\mathrm{H}_{0}$, which states that there isno significant relationship between human resource management and employees' sustainability development

\section{Discussion of the Results}

The outcome presented in table 6 indicates that there is a strong relationship between human resource management practices and employees' sustainability development. The finding of the study in tandem with the aftereffects of Qureshi et al. (2007) that human resource management practices of the firm is emphatically correlated with employees' development and performance.

\section{Conclusion and Recommendations}

From the findings of this research, it is noteworthy that in today's unpredictable and increasingly innovative business environment, the study's result bolsters the conventional wisdom that employees are the most important resource of a business organization and that a successful routine with regards to Human Resource Management Practices to develop and tap this invaluable potential of employees will save the eventual fate of businesses. The significant relationship that the examination inspires between the selected HRM practices and employees' sustainable development is in the help of the different comparative studies and this hence should be indicative to specialists and business practitioners crosswise over the board, not to downplay the importance of HRMP as a key apparatus to achievea similar advantage.

Based on the findings of the study, the following are recommendations for the Branch Managers and other senior officers of banks in Ado-Ekiti, Nigeria:

- Selection of employees should be done according to the standards and morals

- Employees should be provided with adequate training and development projects

- The bank senior officers should maintain a continuous interaction with the employees by updating them on the bank's strategies, procedures and decisions. Management likewise needs to keep the employees very much informed on new developments since all around informed employees settle on sound decisions, remain motivated, productive and feel like an individual from one family in the bank.

- Each bank should have a legitimacy based motivation framework, Putting set up good and reasonable remuneration/reward framework that would specialists to wind up more motivated to accomplish larger amounts of performance.

- Bank management should explain their HRM hone unmistakably in a modified shape.

\section{References}

i. $\quad$ Aguinis, H., 2009. Performance Management. 2nd edition, Person Education, Inc., publishing as Prentice Hall.

ii. Agyapomaa, A. (2011). An Investigation into the Impacts of HRM Practices on Health Workers Motivation at Akim Oda Government Hospital: Ghana, MSc HRM Dissertation submittedto Sheffield Hallam University.

iii. Altarawmneh, I. and M.H. Al-Kilani, 2010. Human Resource Management and Turnover Intentions in the Jordanian Hotel Sector. Research and Practice in Human Resource Management, 18(1): 46-59.

iv. Alvesson, M. and P.O. berg, (1992). Corporate culture and organizational symbolism. Berlin: Walter de Gruyter.

v. Appelbaum, E., T. Bailey, P. Berg and A. Kalleberg, 2000. Manufacturing Advantage: Why High-Performance Systems Pay Off, ILR Press, Ithaca. NY.

vi. Arogyaswamy, B. and C. M. Byles, 1987. Organizational culture: Internal and External Fits, Journal of Management Studies, 13(4): 647-659.

vii. Armstrong, P. (2003). Accountancy and HRM, in J. Storey (Ed.), Human Resource Management: A Critical Text. Routledge, London. 142-16.

viii. Arthur, J.B., 1992. The links between business strategy and industrial relations systems in America steel minimills, Industrial and Labor Relations Review, 45; 488-506.

ix. Bailey, T., 1993. Discretionary Effort and Organization of Work: Employee Participation And Work Reform Since Hawthorne, Working Paper, Columbia University.

x. Barney J. (1991). "Firm Resources and Sustained Competitive Advantage”. Journal of Management, 17(1), 99-120.

xi. Bartel, A.P., 1994. Productivity Gains from the Implementation of Employee Training Programs, Industrial Relations, 33: 411-425.

xii. Becker, B. and B. Gerhart, 1996. The impact of human resource management on the organizationperformance: progress and Prospects, Academy of Management Journal, 39(4): 779-801. 
xiii. Becker, B.E. and M.A. Huselid, 1999. Overview: Strategic Human Resource Management in five leading Firms, Human Resource Management, 38:287-290.

xiv. Bratton, J. and J. Gold, (2001). Human resource management theory and practice. Hound Mills, Palgrave Macmillan.

xv. Chartterjee, S.R and C.A.L. Pearson, (2000). Work Goals and societal Value orientations of Senior Indian Managers: An Empirical Analysis, Journal of Management Development, 19(7): 643-653

xvi. Cooker, F.L., (2000). Manpower restructuring in the state-owned Railway industry of China: The Role of the state in Human Resource Strategy. International Journal of Human Resource Management, 11(5): 321-333.

xvii. Cooper, D., (1998). Improving safety culture, a practical guild. Canada: Routledge.

xviii. Edgar, F. and Geare, A. (2005). HRM practice and employee attitudes: Different measures - different results. Personnel Review, 34(5), 534-549.

xix. Ehnert, I., (2006). 'Sustainability Issues in Human Resource Management: Linkages, theoretical approaches, and outlines for an emerging field'. Paper prepared for 21st EIASM SHRM The workshop, Aston, Birmingham, March $28^{\text {th- }}-29^{\text {th }}, 2006$.

xx. Eisenberger, R, R. Huntington and D. Sava, 1986. Perceived Organizational Support, Journal of Applied Psychology, 71: 500-507.

xxi. Farib, A.M., and Khayal, I., (2015). Axiomatic Design Based Human Resource Management for the Enterprise Transformation of the Abu Dhabi Healthcare Labor Pool. Journal of Enterprise Transformation, 5: 162-191.

xxii. Folger, R.G. and R. Cropanzaro, 1998. Organizational Justice and Human Resource Management, Sage Beverly Hills, CA.

xxiii. Gerhart, B., (1990). Gender differences in current and starting salaries: The role of Performance, college major and job title. Industrial and Labor Relations Review, 43: 418-433.

xxiv. Gould-Williams, J. S. and Davies, F. (2005). Using social Exchange theory to predict the effects of HRM practice on employee outcomes: An analysis of public sector workers. Public Management Review, 7(1), 25-47.

xxv. Guest, D., (2002). Human resource management. Corporate performance and employee wellbeing: building the worker into HRM. The Journal of Industrial Relations, 44(3): 335-358.

xxvi. Hamel, G. and C.K. Prahalad, 1994. Competing for the future, Boston, M.A: Harvard Business School Press.

xxvii. Harel, H.G and S.S Tzafrir, (1999). The Effect of human resource management practices on the perception of organizational and market performance of the firm, Human resource management, Fall, 38(3): 185-200.

xxviii. Hari, G.H and S.S. Tzafrir, (1999). The Effect of human resource management practices on the perceptions of organizational and market performance of the firm, human resource management, Fall, 38(3): 185-200.

xxix. Hendry, C., (1995). Human Resources Management. Routledge.

xxx. Janger, A.R., (1977). The personnel function: Changing objectives and organization. Conference

xxxi. Board, New York.

xxxii. Jones, J.R and Schaubreock, (2004). Mediators of the relationship between race and organizational citizenship behaviour. Journal of Managerial Issues, 16: 505-507.

xxxiii. Qureshi, M. Tahir, H. T., Syed, R. I., and Mohammad (2007). Impact of Human Resource Management Practices on Pakistani organizations J. Bus Policy Res. 3(2): 128-138.

xxxiv. Lado, A.A and Wilson, M.C. (1994). Human Resource Systems and Sustained Competitive Advantage: A Competency-Based Perspective. The Academy of Management Review. Vol. 19, No.4, 699-727.

xxxv. Lengnick-Hall., C. and M. Lengnick-Hall, (1988). Strategic Human resource management: A review of the Literature and a proposed Typology, Academy of Management Review, 13: 454-70.

xxxvi. Locke, E.A, (1976). The handbook of industrial and organizational psychology. New York: Willey

xxxvii. Meggision, M., (1992). Human Resource and Organizational Performance. Nigeria: Calabar

xxxviii. Press Ltd

xxxix. McGregor, D., (1960). The Human Side of Enterprise. New York, McGraw-Hill.

xl. Noe, R.A., Hollenbeck J.R, Gerhart B., and Wright P.M. (2007). Human Resource Management:

xli. Gaining a competitive advantage, USA: McGraw-Hill.

xlii. Owusu, J.A., Antwi, C.O., Ampadu, S. and Osei-Boateng (2016). Assessing the Human Resource Management Practices of Public Banks from Employees' Perspective. Global Journal of Human Resource Management. Vol.4, No.1, 13-30.

xliii. Parker, M., (2000). Organizational Culture and identity. London: Sage Publishing Ltd.

xliv. Porter, M., (1980). Competitive Strategy, the Free Press/ Macmillan, New York.

xlv. Robbins, P. and Judge, A. (2009). Organizational Behavior. New Jersey: Pearson Education, Inc.

xlvi. Schuler, R. S. and Jackson, S. E. (1987). Linking Competitive Strategies with Human Resource Management Practices. The Academy of Management Executive, 3, 207-219.

xlvii. Senyucel, Z. (2009). Managing Human Resources inthe 21 $1^{\text {st }}$ Century. London Ventures Publishing APS.

xlviii. Singh, K., (2004). Impact of Practices on Perceived firm Performance in India. Asia.

xlix. Storey, J. (1992). Developments in the Management of Human Resources. Oxford: Blackwell

1. Sung, J. and Ashton D., (2005). High-Performance work practices. UK: Sage: Linking Strategy,

li. Skill and Performance Outcomes.

lii. Taylor, F. W. (1911). The Principles of Scientific Management, Harper, New York.

liii. Thom, N., (2002). Personal Management: Mehr nachhaltigkeit. In: BAZ.

liv. Thom, N. and Zaugg R. J., (2001). Excellence Curch Personal-und Organisations competent. 
lv. Thom, N. and Zaugg R. J., (2004). Das Prinzip nachhaltigkeit impersonal Management. Personal Fuhrung, (7): 5255.

lvi. Wall, T.A., (2005). The Romance of Human Resource Management and Business Performance. Human Relations, 58/ 4: 423-429. 